\title{
Glimatic influence on the composition of snow cover at Austre Okstindbreen, Norway, 1989 and 1990
}

\author{
He Yuanging ${ }^{*}$ and Wilfred H. Theakstone \\ Department of Geography, University of Manchester, Manchester M13 9PL, England
}

\begin{abstract}
Winter snow cover at Austre Okstindbreen is influenced strongly by patterns of atmospheric circulation, and by air temperatures during precipitation. Differences of circulation over the North Atlantic and Scandinavia during the winters of 1988-89 and 1989-90 were reflected in the ionic and isotopic composition of snow that accumulated at the glacier. Early summer ablation did not remove, or smooth out, all the initial stratigraphic differences. In the first half of the 1988-89 winter, most air masses took a relatively short route between a marine source and Okstindan; late winter snowfalls were from air masses which had taken a longer continental route. The snow that accumulated in the first half of the 1989-90 winter was associated with air masses which had followed longer continental routes, and so brought higher concentrations of impurities from forests, lakes and crustal material. The ablation season began earlier in 1990 than in 1989, and summer winds and rain supplied more impurities to the snowpack surface.
\end{abstract}

\section{INTRODUCTION}

Austre Okstindbreen is the largest glacier of the Okstindan area, northern Norway (Fig. 1). The river water which discharges from it in summer is supplied by both melting glacier ice and melting snow. The proportions of ice meltwater and snow meltwater differ from one year to another, depending principally on climatically driven mass-balance variations. Knowledge of the contributions made to total discharge by ice and snow is needed, because the water is used to generate hydro-electric power. Analyses of 1350 water samples collected at the glacier between 1980 and 1988 revealed that accumulation area sources, strongly depleted of the heavy isotope of oxygen, ${ }^{18} \mathrm{O}$, made a major contribution to discharge (Theakstone, 1991). Knudsen (1990) reported year-to-year variations of the four major cations $\left(\mathrm{Na}^{+}, \mathrm{K}^{+}, \mathrm{Ca}^{2+}, \mathrm{Mg}^{2+}\right)$ present in river water emerging from Austre Okstindbreen, and concluded that they resulted from the differing contributions of snow melt and ice melt to river discharge.

Both the isotopic composition of the snow which accumulates at Austre Okstindbreen and the ionic concentrations in it reflect prevailing climatic conditions during the winter period. In general, winters with lower air temperatures produce snowpacks which are more depleted of ${ }^{18} \mathrm{O}$ than are those which are deposited in milder years. The air masses from which precipitation

\footnotetext{
* Permanent address: Lanzhou Institute of Glaciology and Geocryology, Academia Sinica, Lanzhou, Gansu 730000 , People's Republic of China.
}

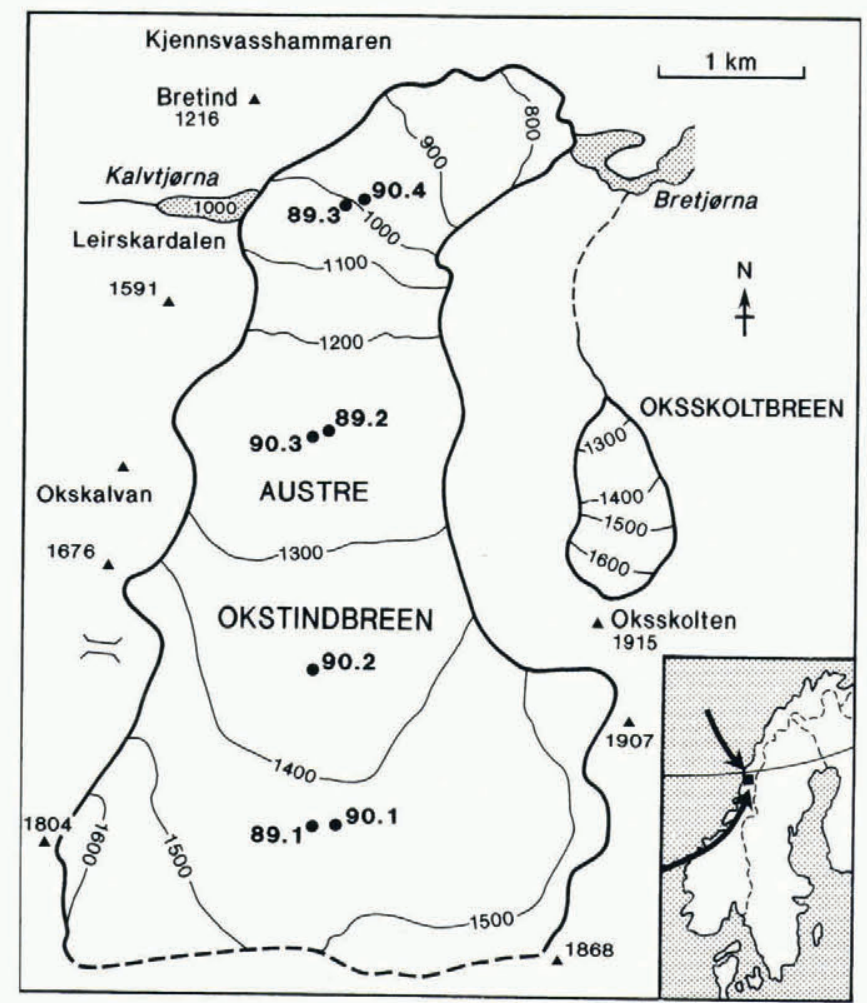

Fig. 1. Austre Okstindbreen. The valley Leirskardalen breaks through the mountain chain at the glacier's western margin. Sites used in 1989 and 1990 snow chemistry studies are indicated. Contours and heights are in metres. Major air mass trajectories are indicated (inset).

falls on the glacier have different moisture source areas and follow different routes to Okstindan. Those which 
reach the area from the south or southwest have a longer overland passage than have those which arrive from the north or northwest (Fig. 1).

This paper focuses on snowpack variations at Austre Okstindbreen in relation to differences of air mass circulation over the North Atlantic and Scandinavia during the winters of 1988-89 and 1989-90. A companion paper (Raben and Theakstone, 1994) deals with altitudinal and seasonal variations of composition of the snowpack.

\section{THE OKSTINDAN AREA}

Okstindan $\left(66^{\circ} \mathrm{N}\right)$ is some $60 \mathrm{~km}$ east of the Norwegian coast and $35 \mathrm{~km}$ south of the town Mo i Rana. Ice divides at about $1510 \mathrm{~m}$ separate the southern part of Austre Okstindbreen's accumulation area from glaciers which flow westwards and southwards. At the western margin, the Okstinden-Okskalvan range, which rises to $1804 \mathrm{~m}$, is broken by cols at $1580-1420 \mathrm{~m}$ (Fig. 1). At the eastern margin, a mountain chain with a north-south trend includes Oksskolten $(1915 \mathrm{~m})$, the highest mountain of northern Norway. Although there is some permanent snow on the mountain slopes up to $1700 \mathrm{~m}$, most of the $14 \mathrm{~km}^{2}$ accumulation area is below $1500 \mathrm{~m}$ (Knudsen, 1992). The mean equilibrium-line altitude is close to $1200 \mathrm{~m}$, but some residual snow is normally present in summer at around $1000 \mathrm{~m}$, close to the head of the valley, Leirskardalen, at the western margin of the glacier. The glacier terminates at $730 \mathrm{~m}$. Between $1200 \mathrm{~m}$ and $1000 \mathrm{~m}$ it is steep and heavily crevassed.

\section{GLIMATE AND SNOW AGGUMULATION AT OKSTINDAN}

There are no permanent meteorological stations in the Okstindan area. Air temperature and precipitation are recorded daily at Mo i Rana, which lies at the head of the Ranafjord, at about $30 \mathrm{~m}$ a.s.l. Annual snow accumulation, determined at Austre Okstindbreen as part of a programme of mass-balance studies (Knudsen, 1992), usually begins in September and little melting occurs before June. Normally, more precipitation falls during the first half of the winter (October-May) than in the second, and January is the coldest month (Fig. 2). Winter accumulation is generally more than twice the precipitation at Mo i Rana in the same period. The proportion of the total snow which accumulates in each month is estimated from the Mo i Rana data (Fig. 2). Local topography influences the exposure of the glacier to precipitation-bearing air masses. Air masses which follow longer overland routes to Okstindan acquire more impurities from forests, lakes and crustal material than do those which have a shorter continental route from a marine source.

More than one third of the 1988-89 winter precipitation at Mo i Rana fell in the first three months, which were relatively cold (Fig. 2) although, in December, mild air was carried into Scandinavia along the northern side of the Azores high, which was displaced to the north. In January the Azores high extended still further to the northeast, whilst the Iceland low was unusually deep. These conditions led to mild, wet weather in Scandinavia:
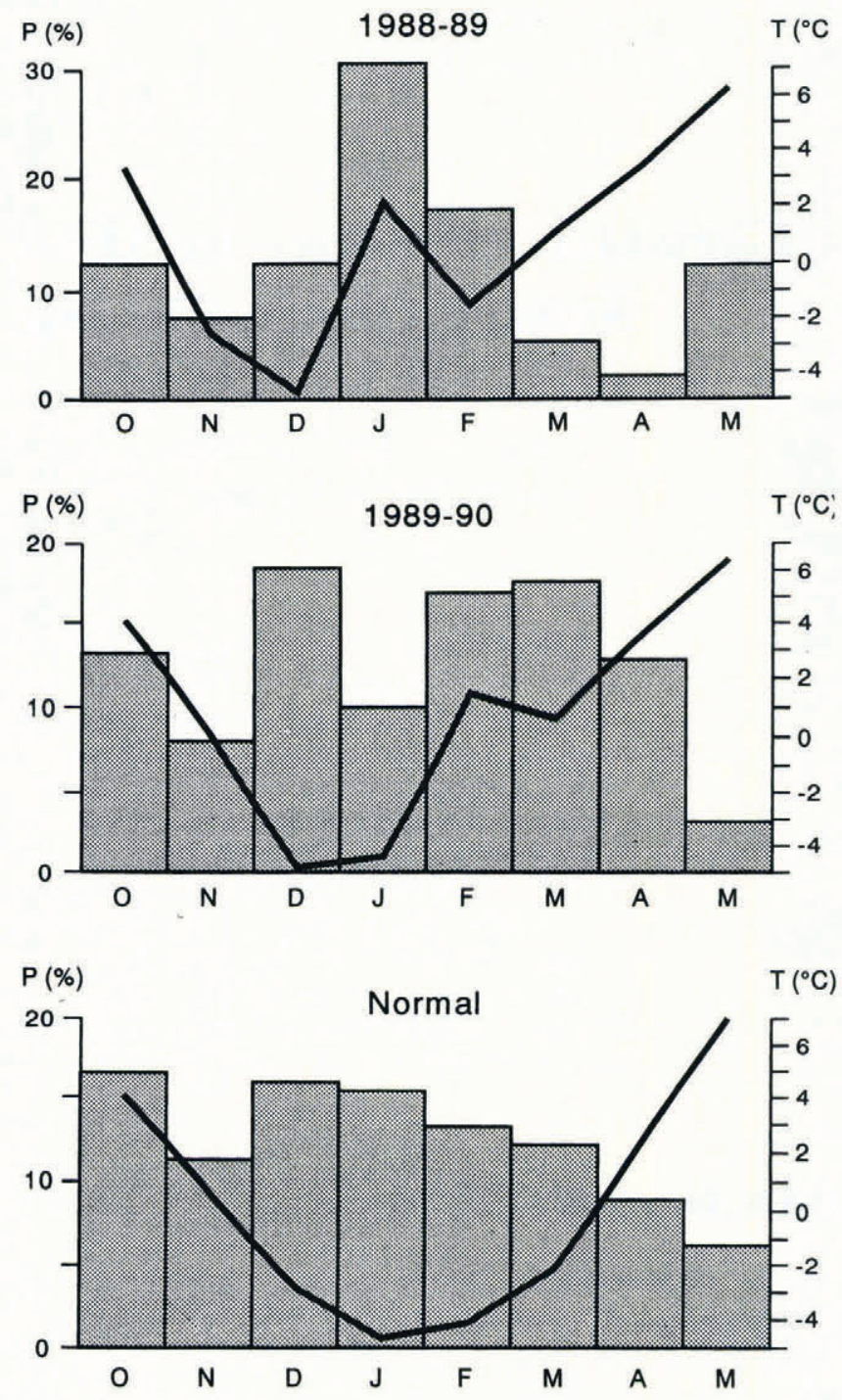

Fig. 2. Mean monthly temperature $\left({ }^{\circ} \mathrm{C}\right)$ and percentage of the winter (October-May) precipitation falling in each month at Mo $i$ Rana. Both the winter of 1988-89 and that of 1989-90 deviated from the $30 y$ r normal (bottom). Winter precipitation was more evenly distributed in 1989 90 than in the previous year.

more than one quarter of the winter's precipitation at Mo i Rana fell in this month. The last half of the winter was rather mild. In April and May, high-latitude high pressure was dominant and precipitation was below average.

About $30 \%$ of the $1989-90$ winter precipitation fell in December and January, the two coldest months. Air masses which resulted in snowfall during the first half of the winter generally had a longer overland passage, from the south or southwest, than those which had resulted in snowfall in the same period in 1988-89. March and April were much wetter than in 1989, as the Iceland low extended well to the east, north of Scandinavia. The ablation season began earlier in 1990 than in 1989, and summer ablation was more rapid than in the previous year. The differences of atmospheric circulation in the two winters influenced both spatial and temporal variations of the chemical composition of the snow pack at Austre Okstindbreen. 
Table 1. Snow pits at Austre Okstindbreen, 1989 and 1990 (N, number of samples; L, length of samples; Sampling date, year, month, day). Pits 89.2, 89.3 and 90.4 reached the previous summer's surface

$\begin{array}{cccccc}\text { Altitude } & \text { Depth } & \mathcal{N} & L & \begin{array}{c}\text { Sampling } \\ \text { date }\end{array} & \text { Comments } \\ \text { ma.s.l. } & \mathrm{m} & & \mathrm{cm} & & \end{array}$

$\begin{array}{lrrrrrr}89.1 & 1450 & 2.16 & 18 & 12 & 890721 & \text { 2 samples lost } \\ 89.2 & 1250 & 1.92 & 16 & 12 & 890724 & 890717 \\ 89.3 & 1000 & 2.76 & 22 & 12 & 900507 & \text { 1 sample lost } \\ 90.1 \mathrm{~A} & 1470 & 2.40 & 24 & 10 & 900715 & \text { 1 sample lost } \\ 90.1 \mathrm{~B} & 1470 & 2.07 & 39 & 5.5 & 900724 & \\ 90.2 & 1370 & 1.80 & 28 & 10 & 900720 & \\ 90.3 & 1230 & 2.80 & 18 & 10 & 500716 & 900726 \\ 90.4 & 980 & 1.89 & 38 & 10 & \end{array}$

\section{SAMPLE COLLECTION AND ANALYSIS, 1989 AND 1990}

In July 1989 sampling was undertaken at three pits (Fig. 1, Table 1). At the highest ( $1450 \mathrm{~m}$ a.s.l.), the previous summer's surface was at a depth of about $6 \mathrm{~m}$. The other pits reached glacier ice. The pit at $1000 \mathrm{~m}$ was in a zone of residual net accumulation below the general level of the transient equilibrium line; the site is more exposed to westerly winds than is most of the glacier, because the valley Leirskardalen breaks the north-south mountain barrier. In May 1990 samples were taken from the top $2.2 \mathrm{~m}$ of the snowpack at $1470 \mathrm{~m}$. In July 1990, when coring revealed that the dirty 1989 summer surface at this site was $4.5 \mathrm{~m}$ below the upper surface of the snowpack, samples were collected at 1470, 1370, 1230 and $980 \mathrm{~m}$ (Fig. 1, Table 1). The pit at the lowest site reached glacier ice. A core was taken from the bottom of the pit at $1370 \mathrm{~m}$, to a total below-surface depth of $6.5 \mathrm{~m}$; the 1989 summer surface was identified at $4.1 \mathrm{~m}$.

Sample thickness varied from pit to pit, but samples collected at a particular site were of uniform thickness. Separate samples collected for isotopic and ionic analyses were allowed to melt in sealed polythene bags before being transferred to randomly selected polyethylene flasks and vials. The core was taken with a PICO corer (Koci and Kuivinen, 1984); samples were divided in the field before being treated in the same way as pit-wall samples. $\delta^{18} \mathrm{O}$ values of 273 snow and firn samples and 329 river water samples were determined at the Geophysical Isotope Laboratory of the University of Copenhagen. Cations were determined by AAS spectrophotometry at the Department of Geography, University of Manchester, and anions by ion chromatography at the Department of Geology, University of Manchester.

\section{RESULTS OF ISOTOPE ANALYSES}

In 1989 , the mean $\delta^{18} \mathrm{O}$ value at $1450 \mathrm{~m}$ (site 89.1) was $-12.91 \%$ (Table 2). Values were relatively high between the surface and $0.48 \mathrm{~m}$, and between $1.56 \mathrm{~m}$ and $2.16 \mathrm{~m}$; between $0.48 \mathrm{~m}$ and $1.56 \mathrm{~m}$, they were low (Fig. 3). At $1250 \mathrm{~m}$ (site 89.2 , mean $\delta^{18} \mathrm{O}$ value: $-11.03 \%$ ), the top half-metre of snow was isotopically heavier than that beneath, to a depth of $1.32 \mathrm{~m}$. The sample between $1.32 \mathrm{~m}$ and $1.44 \mathrm{~m}$ was ${ }^{18} \mathrm{O}$-rich $\left(\delta^{18} \mathrm{O}:-10.39 \%\right.$ ). Below this, $\delta^{18} \mathrm{O}$ values varied only slightly (Fig. 3). At $1000 \mathrm{~m}$

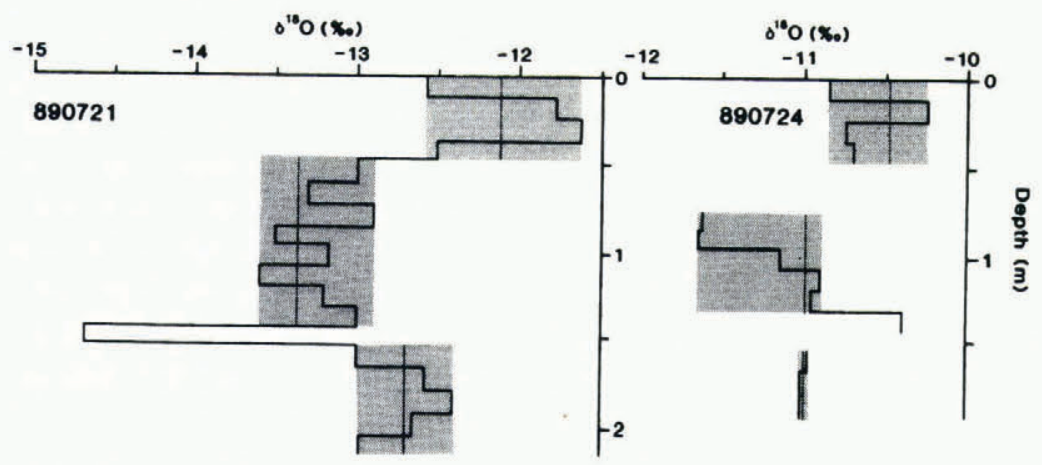

Fig. 3. In July 1989 the range of $\delta^{18} O$ values in the top $2 \mathrm{~m}$ of the snow cover at Austre Okstindbreen was much larger at $1450 \mathrm{~m}$ (left) than at $1250 \mathrm{~m}$ (right). More of the previous winter's snow had melted from the lower site than from the higher one. At both sites, samples at around $1 \mathrm{~m}$ depth were more depleted of ${ }^{18} \mathrm{O}$ than was the top $0.5 \mathrm{~m}$. The thin vertical lines represent the mean $\delta^{18} \mathrm{O}$ values of the shaded groups of samples. 
(site 89.3 , mean $\delta^{18} \mathrm{O}$ value: $-11.01 \%$ ), there were some large differences of $\delta^{18} \mathrm{O}$ values between adjacent samples; the lower part of the snowpack $\left(1.92-2.64\right.$ m: mean $\delta^{18} \mathrm{O}$ value: $-11.65 \%$ ) was more depleted of the heavy isotope than was the rest.

The substantial range of $\delta^{18} \mathrm{O}$ values of samples collected in May 1990 at $1470 \mathrm{~m}$ (mean: $-12.37 \%$, maximum: $-8.20 \%$, minimum: $-17.20 \%$ ) (Fig. 4) indicated that air temperatures at the site during episodes of accumulation had differed considerably.

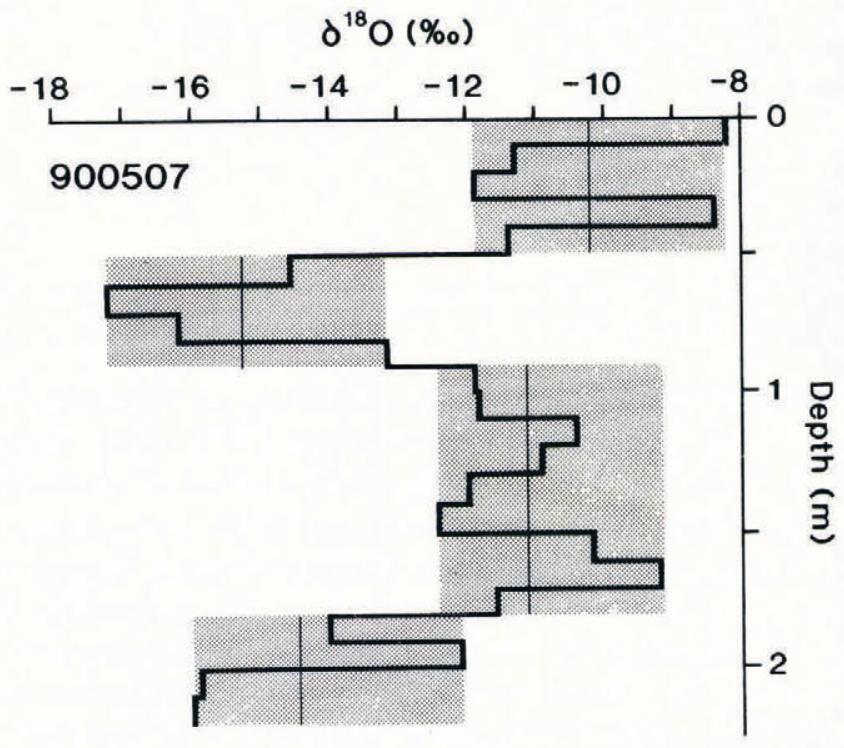

Fig. 4. In May 1990 the range of $\delta^{18} \mathrm{O}$ values in the top $2 \mathrm{~m}$ of the snow cover at Austre Okstindbreen was very high. In part this reflected winter climate variations, with low temperatures in December and January. The thin vertical lines represent the mean $\delta^{18} O$ values of the shaded groups of samples.

In July 1990, the mean $\delta^{18} \mathrm{O}$ value at $1470 \mathrm{~m}$ (site 90.1 ) was relatively high $(-10.74 \%$ ). At $1370 \mathrm{~m}$ (site 90.2$)$, the pattern of isotope ratios in the old snow, down to $4.1 \mathrm{~m}$, was more complex than that in the underlying firn, which was characterized by a progressive enrichment in ${ }^{18} \mathrm{O}$ (Fig. 5). Isotopic homogenisation was particularly

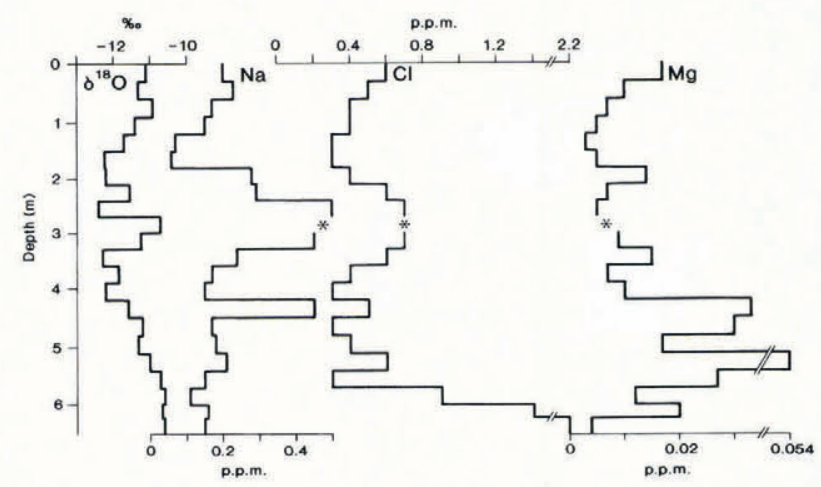

Fig. 5. In fuly 1990, at $1370 \mathrm{~m}$, firn was covered by $4.1 \mathrm{~m}$ of snow. $\delta^{18} \mathrm{O}$ variations were much smaller in the firn than in the snow. Ionic concentrations were high at the 1989 summer surface. One sample collected for ionic analysis, at

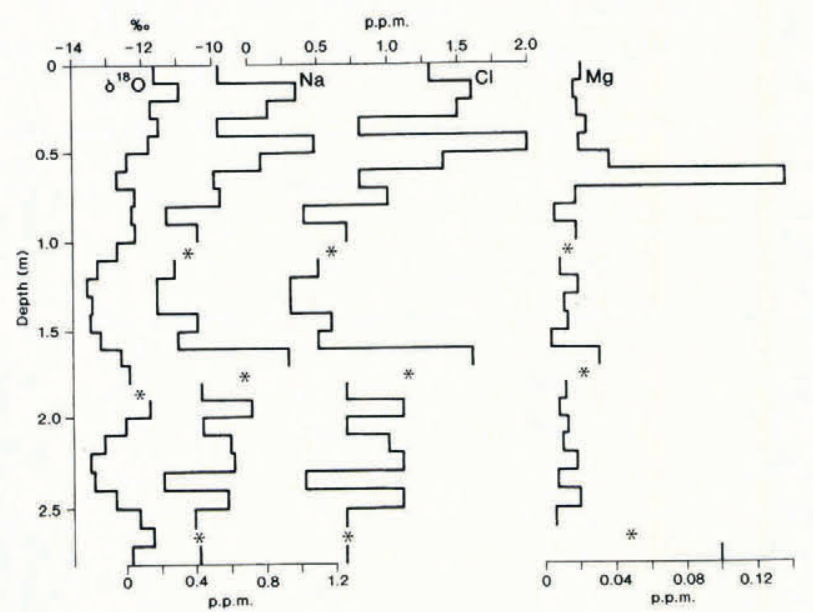

Fig. 6. In July 1990 the pattern of variations of the ${ }^{18} \mathrm{O}$ content of the snow cover at $1230 \mathrm{~m}$ was similar to that of the other major ions. Three samples $\left({ }^{*}\right)$ - one collected for isotope analysis and two collected for ionic analyseswere lost.

pronounced in the lowest metre of the core, between 5.5 and $6.5 \mathrm{~m}$. The mean $\delta^{18} \mathrm{O}$ value of the old snow was $-11.67 \%$, that of the underlying firn $-10.96 \%$. At $1230 \mathrm{~m}$ (site 90.3 ) the $\delta^{18} \mathrm{O}$ values were at a minimum in the centre of the profile (Fig. 6); the mean was $-12.51 \%$. At $980 \mathrm{~m}$ (site 90.4), on $16 \mathrm{July}$, the mean $\delta^{18} \mathrm{O}$ value was $-12.68 \%$. In the following ten days, as the snow thickness decreased by $0.94 \mathrm{~m}$, principally as a result of melting, the pack became isotopically more homogeneous, and the mean $\delta^{18} \mathrm{O}$ value rose to $-11.25 \%$.

\section{RESULTS OF IONIC ANALYSES}

All ionic concentrations were low, but mean values for the samples collected at $1470 \mathrm{~m}$ in May 1990 were much higher than those found in the summer field seasons. Relatively large amplitude variations were present within the late-winter snowpack.

In July 1989, mean ionic concentrations decreased with altitude (Table 2). At $1450 \mathrm{~m}$, maximum concentrations of individual ions were at different depths, but $\mathrm{Ca}^{2+}$ and $\mathrm{Mg}^{2+}$ variations were similar. $\mathrm{Cl}^{-}$concentrations were more variable than were those of the other major ions. $\mathrm{NO}_{3}{ }^{-}$and $\mathrm{Br}^{2-}$ were detected in only four samples. At $1250 \mathrm{~m}, \mathrm{Na}^{+}$and $\mathrm{K}^{+}$displayed similar stratigraphic variations, as did $\mathrm{Ca}^{2+}$ and $\mathrm{Mg}^{2+}$. Concentrations were lower than at $1450 \mathrm{~m}$, and were highest in the lower part of the profile. At $1000 \mathrm{~m}$, stratigraphic variations of each of the four principal ions were similar. Mean concentrations were low (Table 2), but those in snow which was bounded by ice layers at depths of $0.6 \mathrm{~m}$ and $1.0 \mathrm{~m}$ were high.

In July 1990 concentrations of most ions at $1370 \mathrm{~m}$ tended to decrease downwards from the surface to a depth of about $1.5 \mathrm{~m}$ (Fig. 5), and the 1989 summer surface, at $4.1 \mathrm{~m}$, was marked by high concentrations of most ions. In the firn, concentrations of $\mathrm{Na}^{+}$were low, but those of other ions, including $\mathrm{SO}_{4}{ }^{2-}$, were relatively high. At 
Table 2. Mean ionic concentrations (ppm) and mean $\delta^{18} O$ values (\%o), Austre Okstindbreen

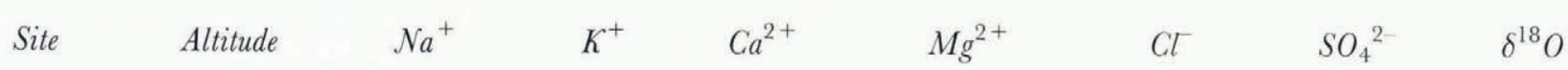

$\mathrm{m}$

$\begin{array}{lrlllllll}89.1 & 1450 & 0.33 & 0.06 & 0.12 & 0.07 & 0.79 & & -12.91 \\ 89.2 & 1250 & 0.21 & 0.05 & 0.12 & 0.02 & & & -11.03 \\ 89.3 & 1000 & 0.17 & 0.04 & 0.12 & 0.02 & 0.56 & 0.04 & -11.01 \\ 90.1 \mathrm{~A} & 1470 & 0.49 & 0.08 & 0.13 & 0.17 & 1.58 & 0.29 & -12.37 \\ 90.2 & 1370 & 0.22 & 0.03 & 0.15 & 0.02 & 0.58 & & -11.67 \\ 90.3 & 1230 & 0.52 & 0.12 & 0.14 & 0.02 & 0.91 & & -12.51 \\ 90.4 & 980 & 0.49 & 0.15 & 0.11 & 0.02 & 0.97 & 0.13 & -11.25 \\ & & & & & & & & \end{array}$

$1230 \mathrm{~m}$, patterns of distribution of $\mathrm{Na}^{+}, \mathrm{Cl}^{-}$and $\mathrm{K}^{+}$were similar, with generally higher values above a minimum at 1.0-1.5 m depth (Fig. 6). Mean concentrations were well above those at site $1370 \mathrm{~m}$ (Table 2). At $980 \mathrm{~m}$, where all ions displayed similar stratigraphic patterns, mean concentrations were relatively high (Table 2 ).

\section{DISCUSSION}

Many individual snowfalls contribute to the snow cover which is present at Okstindan towards the end of the winter. They differ in their composition, partly because different aerosols and moisture sources have been incorporated in the air masses from which precipitation occurs, and partly because the air masses have followed different routes from the ocean. Snow falling from an air mass which has traversed a substantial area of terrain of increasing altitude has a relatively low heavy isotope content. If the snow is precipitated from an air mass which has moved directly from the coast with little increase of altitude, its $\delta$ value is likely to be higher. At the end of a cold winter, the snow cover is more depleted of ${ }^{18} \mathrm{O}$ than at the end of a mild one, because the isotopic composition of precipitation is temperature-dependent: $\delta$ values are lower in colder periods (Dansgaard, 1964). Because the 1989-90 winter was colder than that of 1988$89, \delta^{18} \mathrm{O}$ values of the snowpack at Austre Okstindbreen were lower at the start of the 1990 summer than at the same time in the previous year.

Most of the snow sampled at the lower sites in July 1989 had accumulated during the first half of winter, that which fell later having been lost by ablation before samples were collected. However, when samples were collected at the highest site $(1450 \mathrm{~m})$, much of the snow which had fallen in February and March still remained, because of the later onset of ablation there. In July 1990, more of the previous winter's accumulation had melted at $1230 \mathrm{~m}$ than at $1350 \mathrm{~m}$, and even more had gone at $1000 \mathrm{~m}$.

$\mathrm{Na}: \mathrm{Cl}$ ratios indicate that marine sources dominate the snow deposited at Austre Okstindbreen. Other sources, including forests, lakes and crustal material, supply minor ionic species. The introduction of partic- ulate matter to Austre Okstindbreen's accumulation area by winds and rainfall during the ablation season, which began earlier in 1990 than in 1989, was responsible, in part, for the higher near-surface concentrations of cations and anions at $1350 \mathrm{~m}$ and $1230 \mathrm{~m}$ in 1990 .

During the ablation season, elution of ions as meltwater percolates down through the snow results in depletion of solutes in the remaining pack, and causes differential changes of their concentration at particular depths. Percolation is hindered by ice layers within the pack and by the underlying glacier ice. Associated enrichment of adjacent snow was found at $1250 \mathrm{~m}$ and $1000 \mathrm{~m}$ in 1989. Although ablation and compaction between 5 May and 15 July 1990 resulted in $0.8 \mathrm{~m}$ surface lowering at $1470 \mathrm{~m}$, some of the initial differences of isotopic composition were not smoothed out by water percolation through the pack, and associated ${ }^{18} \mathrm{O}$ enrichment.

\section{CONCLUSIONS}

The winter snowpack at Austre Okstindbreen is built up by a succession of snowfalls. Its chemical (isotopic and ionic) composition is influenced by air mass trajectories and by air temperatures during precipitation in winter months. Early-summer ablation neither removes nor smooths out all the initial stratigraphic differences; the tendency towards isotopic homogenisation is more pronounced at lower altitudes, where melting of snow begins earlier.

In the first half of the 1988-89 winter, most air masses took a relatively short route between a marine source and Okstindan; late-winter snowfalls were from air masses which had had a longer continental route. In July 1989 the influence of newly acquired, non-marine impurities was more evident at $1450 \mathrm{~m}$ than at lower altitudes, where there had been more ablation.

The snow which accumulated during the first half of the 1989-90 winter was associated with air masses which had followed longer continental routes, and so brought higher concentrations of impurities from forests, lakes and crustal material. The low temperatures of December and January were reflected in low $\delta^{18} \mathrm{O}$ values in the 
accumulated snow. Because the ablation season began earlier in 1990, summer winds and rain supplied more impurities to the snowpack surface than in 1989.

\section{ACKNOWLEDGEMENTS}

We thank Tvis Knudsen and Frank Jacobsen of the Geological Institute, University of Aarhus for their companionship and assistance in the field, personnel from the Copenhagen University Geophysical Laboratory for isotope analyses, and Nick Scarle for cartographic work. The research was undertaken whilst Theakstone was in receipt of a Research Grant (GR3/3783) from the U.K. Natural Environment Research Council. He Yuanqing, who was supported by an Overseas Research Student Award and a University of Manchester Postgraduate Award, received financial assistance from the Universities' China Committee in London for field research at Okstindan.

\section{REFERENGES}

Dansgaard, W. 1964. Stable isotopes in precipitation. Tellus, 16(4), 436468.

Knudsen, N. T. 1990. Dissolved load in glacier river water, Austre Okstindbreen, Okstindan, Norway. Manchester, University of Manchester. Department of Geography. (Okstindan Glacier Project Report 90.2.)

Knudsen, N. T. 1992. Mass balance, meltwater discharge and ice velocity at Austre Okstindbreen, Nordland, Norway, 1990-91. Manchester, University of Manchester. Department of Geography. (Okstindan Glacier Project Report 92.1.)

Koci, B. R. and K. C. Kuivinen. 1984. The PICO lightweight coring auger. J. Glaciol., 30(105), 244-245.

Raben, P. and W. H. Theakstone. 1994. Isotopic and ionic changes in a snow cover at different altitudes: observations at Austre Okstindbreen in 1991. Ann. Glaciol., 19 (see paper in this volume).

Theakstone, W. H. 1991. Stable isotope investigations at Austre Okstindbreen, 1980-1990. Manchester, University of Manchester. Department of Geography. (Okstindan Glacier Project Report 91.3.)

The accuracy of references in the text and in this list is the responsibility of the authors, to whom queries should be addressed. 